\title{
Purification and Characterization of Leucocidin from Pseudomonas aeruginosa
}

\author{
By W. SCHARMANN* \\ Institut für Bakteriologie und Immunologie, Fachbereich Veterinärmedizin, \\ Universität Giessen, D-63 Giessen, Germany
}

(Received 6 June 1975; revised 19 September 1975)

\begin{abstract}
SUMMARY
Leucocidin from Pseudomonas aeruginosa strain 158 was released from bacteria by autolysis and purified 19 -fold by ammonium sulphate precipitation $(20 \%$ saturation) and combined 'tandem' gel filtration on Sephadex G-I00 superfine and Bio Gel P-I00. The product gave a single band (mol. wt. 27000) after polyacrylamide gel electrophoresis with sodium dodecyl sulphate (SDS). However, it was separated into two active peaks ( $\mathrm{pI} 5.0$ and 5.2 ) by isoelectric focusing, and into five bands by disc electrophoresis without SDS. All bands contained leucocidic activity of about the same specific activity and retained their homogeneity.

The purified toxin was thermolabile and was inactivated by pronase, but not by several other proteases. The ultraviolet light absorbancy was typical of proteins. Antibodies directed against leucocidin were detected by passive haemagglutination and by toxin-neutralization. These antibodies inhibited the cytotoxic action of leucocidin bound to granuloyctes. The toxin damaged all tested leucocytes (granulocytes of various animal species and lymphocytes of humans) and a number of tissue cultures, but was ineffective against erythrocytes, thrombocytes and isolated granules from polymorphonuclear leucocytes. The intravenous lethal dose for mice was about I $\mu \mathrm{g}$.
\end{abstract}

\section{INTRODUCTION}

The occurrence of a leucocidin in Pseudomonas aeruginosa strain 158 is reported in the preceding paper (Scharmann, 1976). It was active on human polymorphonuclear leucocytes (Scharmann, Jacob \& Porstendörfer, I976), but not on erythrocytes.

This paper deals with the purification and characterization of the leucocidin and its toxicity for mice, leucocytes and various cell cultures.

\section{METHODS}

Bacterial strain. Pseudomonas aeruginosa, strain 158, was used for the production of leucocidin (Scharmann, 1976).

Buffer. Phosphate buffered saline $\mathrm{pH} 7 \cdot 2$ (PBS) was prepared according to Dulbecco \& Vogt (1954).

Preparation of autolysate. Autolysate was prepared as described (Scharmann, 1976). Bacteria were cultivated for $22 \mathrm{~h}$, washed once with PBS, resuspended in PBS to one-tenth of the original culture volume and shaken for $56 \mathrm{~h}$ at $37^{\circ} \mathrm{C}$. The supernatant of the autolysate was collected by centrifugation $(37000 \mathrm{~g}, 40 \mathrm{~min})$.

Measurement of leucocidic activity. Leucocidin was usually estimated as described in the preceding paper (Scharmann, 1976). In some experiments ${ }^{51} \mathrm{Cr}$-labelled target cells $\left(2 \times 10^{7}\right)$

* Present address: Bundesgesundheitsamt. D-1, Berlin 33, Postfach, Germany. 
were incubated with leucocidin for $60 \mathrm{~min}$ at $37^{\circ} \mathrm{C}$ and the supernatant of the suspension collected by centrifugation ( $12000 \mathrm{~g}$, I5 s, Eppendorf centrifuge; Eppendorf Gerätebau Netheler \& Hinz, Hamburg, Germany). The radioactivity of the supernatant was measured in an autogamma spectrometer (Packard Instrument Co. Inc. La Grange, Illinois, U.S.A.) and expressed as a percentage of the total activity released from the target cells by $0.2 \%$ (v/v) Triton X-100.

Leucocytes. Polymorphonuclear leucocytes from humans, rabbits, guinea pigs and mice were obtained by the slide adhesion method (Gladstone \& van Heyningen, 1957). Granulocytes from cattle, sheep and dogs were prepared according to the method of Behrens \& Esch (1963). One vol. blood was mixed with 2 vol. water. Isotonic conditions were restored after $55 \mathrm{~s}$ by the addition of $0.5 \mathrm{vol}$. of a $4.5 \%(\mathrm{w} / \mathrm{v}) \mathrm{NaCl}$ solution and the granulocytes collected by centrifugation at $150 \mathrm{~g}$ for $10 \mathrm{~min}$.

Human lymphocytes were isolated by incubation of venous blood with glass beads and subsequent density gradient centrifugation on a mixture of Ficoll (Pharmacia) and Isopaque (Nyegaard \& Co., Oslo, Norway) (Seiler et al., 1972).

Thrombocytes. Human platelets were prepared as described by Cox, Hardegree \& Fornwald (1974). A platelet suspension ( $\mathrm{I} \mathrm{ml}$ ) in PBS with an $E_{650}$ of about 0.6 was examined for susceptibility to lysis by incubation for $\mathrm{I} \mathrm{h}$ at $37^{\circ} \mathrm{C}$ with $2500 \mathrm{MLeD}$ leucocidin, where I MLeD (minimal leucocidic dose) was the highest dilution of toxin which destroyed all the leucocytes of a field (about 6000 to 8000 granulocytes).

Granules. For isolating granules from bovine polymorphonuclear leucocytes, the method of Hegner (1968) was used. The granules were suspended in PBS to give an $E_{405}$ of 0.5 and incubated for $60 \mathrm{~min}$ at $37^{\circ} \mathrm{C}$ with either $2500 \mathrm{MLeD}$ leucocidin or $10 \mathrm{MHD}$ haemolysin, where I MHD (minimal haemolytic dose) was the amount of toxin required to cause $50 \%$ lysis of a I $\%(v / v)$ sheep erythrocyte suspension. The granule-free supernatant was obtained by centrifugation ( $12000 \mathrm{~g}, 2 \mathrm{~min}$ ) and assayed for cathepsin, $\beta$-glucuronidase and alkaline phosphatase.

Target cells. Bovine polymorphonuclear leucocytes $\left(\mathrm{I} \times 10^{8}\right)$ in PBS were incubated for 30 min at $37^{\circ} \mathrm{C}$ with $100 \mu \mathrm{Ci} \mathrm{Na}{ }^{51} \mathrm{Cr}$ (Behringwerke, Marburg, Germany). After incubation the cells were washed three times with PBS.

Tissue cultures. The following tissue cultures were used: primary cultures of calf testicular cells, and rabbit kidney cells as diploid cells; serially propagated cultures of epithelioid green monkey kidney cells, L-cells, and HeLa cells as heteroploid cells. All cells were grown in Eagle's basal medium supplemented with bovine foetal serum ( 2 to $10 \%, \mathrm{v} / \mathrm{v})$, penicillin (100 u. $\left.\mathrm{ml}^{-1}\right)$ and streptomycin $\left(100 \mu \mathrm{g} \mathrm{ml}^{-1}\right)$. Each culture contained about $2 \times 10^{6} \mathrm{cells} / \mathrm{ml}$. For examining the cytopathogenic effect of leucocidin, the culture medium was replaced by PBS and the tissue cultures incubated with $100 \mathrm{MLeD}$ leucocidin $/ \mathrm{ml}$ for $30 \mathrm{~min}$ at $37^{\circ} \mathrm{C}$.

Purification of haemolysin. Haemolysin from $P$. aeruginosa strain 158 was partially purified as described by Berk (1964).

Assays. $\beta$-glucuronidase was determined after $\mathrm{I} 6 \mathrm{~h}$ of incubation with phenolphthalein glucuronidate (Fishman, Springer \& Brunetti, 1948). Cathepsin was assayed according to Anson (1936), using haemoglobin. Lactate dehydrogenase was estimated with the Boehringer kit (Boehringer Mannheim, Mannheim, Germany) according to the suggestions of the manufacturer. Alkaline phosphate was measured by the method of Bessey, Lowry \& Brock (1946) with $p$-nitrophenylphosphate as the substrate. Haemolytic and proteolytic activity and protein concentration were measured as described in the preceding paper (Scharmann, I976).

Isoelectric focusing. An LKB 8I I I ( I $\mathrm{m}$ ml) column (LKB produkter, Stockholm-Bromma, 
Sweden) was used to focus about $5 \mathrm{mg}$ protein in a density gradient (o to $50 \%$ ) of sucrose or urea. The carrier ampholytes (LKB; 0.9 to $3.75 \%$ ) ranged from $\mathrm{pH}_{3}$ to io and from $\mathrm{pH} 4$ to 6 . Focusing was conducted for $26 \mathrm{~h}$ at $4{ }^{\circ} \mathrm{C}$, the final potential being I Ioo V.

Polyacrylamide disc gel electrophoresis. The general procedures and buffers described by Davis (I964) were used. The concentration of acrylamide in the separating gel was $7.5 \%$ (w/v) unless otherwise stated. Gels were stained in an amido black $10 \mathrm{~B}$ solution and destained with $10 \%(\mathrm{v} / \mathrm{v})$ acetic acid. The positions of the proteins in unstained gels were determined by scanning the gels at $280 \mathrm{~nm}$ in a Gilford model 240 recording spectrophotometer (Gilford Instruments, Oberlin, Ohio, U.S.A.) fitted with a linear transporter. For calculating the molecular weight of leucocidin, sodium dodecyl sulphate-polyacrylamide gel electrophoresis was performed by the method of Weber \& Osborn (1969) with bromophenol blue as tracking dye. The reference proteins, with their molecular weights, included: pepsin (35000), chymotrypsin (25700), trypsin (23300), lactoglobulin (I8200), and myoglobin (I7800).

Preparation of antisera. Samples containing $500 \mu \mathrm{g}$ toxin $/ \mathrm{ml}$, purified by gel filtration, were injected into rabbits (average weight $3 \mathrm{~kg}$ ). Injections were given at 3 to 4 day intervals. Five subcutaneous $(0.2$ to $0.8 \mathrm{ml}$ ) and two intramuscular (each $0.6 \mathrm{ml}$ ) injections were given. One week after the last injection, blood was collected by cardiac puncture and the serum fraction stored at $-30^{\circ} \mathrm{C}$ until used.

Passive haemagglutination test. The procedure was as described previously (Sezen, Scharmann \& Blobel, I975).

Determination of lethality to mice. Groups of four mice each weighing about $20 \mathrm{~g}$ were injected intravenously with $0.1 \mathrm{ml}$ leucocidin dilutions in PBS.

Materials. Trypsin, alpha chymotrypsin, pancreatic elastase, pronase, pepsin, chymotrypsinogen, lactoglobulin, myoglobin (horse), haemoglobin (cattle), $p$-nitrophenylphosphate, phenolphthalein glucuronidate, iodoacetamide, $p$-hydroxymercuribenzoate, cysteine, Eagle's basal medium and polyethylene glycol 20000 were obtained from Serva, Heidelberg, Germany. Papain, subtilisin BPN', subtilisin Carlsberg, sphingomyelin, and brain extracts I, III and V were obtained from Sigma. Casein (Hammarsten), cholesterol and urea of analytical grade were purchased from Merck. Sephadex G-I0o superfine was obtained from Pharmacia. Bio Gel P-I0o was a product of Bio Rad Laboratories, Richmond, California, U.S.A.

\section{RESULTS}

\section{Purification of leucocidin}

After several preliminary experiments using different methods of precipitation and chromatography, the purification scheme shown in Fig. I was found to give the best results. All steps were carried out at $4^{\circ} \mathrm{C}$.

Step I: ammonium sulphate fractionation. The supernatant fluid from autolysed $P$. aeruginosa cultures (I50 ml) was cooled to $4{ }^{\circ} \mathrm{C}$ and $37.5 \mathrm{ml}$ of a saturated ammonium sulphate solution $\mathrm{pH} 7 \cdot 2$ was added dropwise with stirring. Stirring was continued overnight and the precipitate collected by centrifugation at $22000 \mathrm{~g}$ for $\mathrm{I} 5 \mathrm{~min}$. The precipitate was dissolved in $10 \mathrm{ml}$ PBS containing $0.2 \mathrm{M}-\mathrm{NaCl}, \mathrm{pH} 7 \cdot 2$, stirred overnight, and the soluble fraction obtained by centrifugation $(22000 \mathrm{~g}$, I $5 \mathrm{~min}$.). The remaining precipitate was extracted once again in the same way. When the fractionation was performed with saturation grades higher than $20 \%$ ammonium sulphate, the insolubility of the resulting precipitate increased so that no higher activities of soluble leucocidin were obtained. Moreover, at $20 \%$ saturation only a small part of the protease (elastase) originally in the 


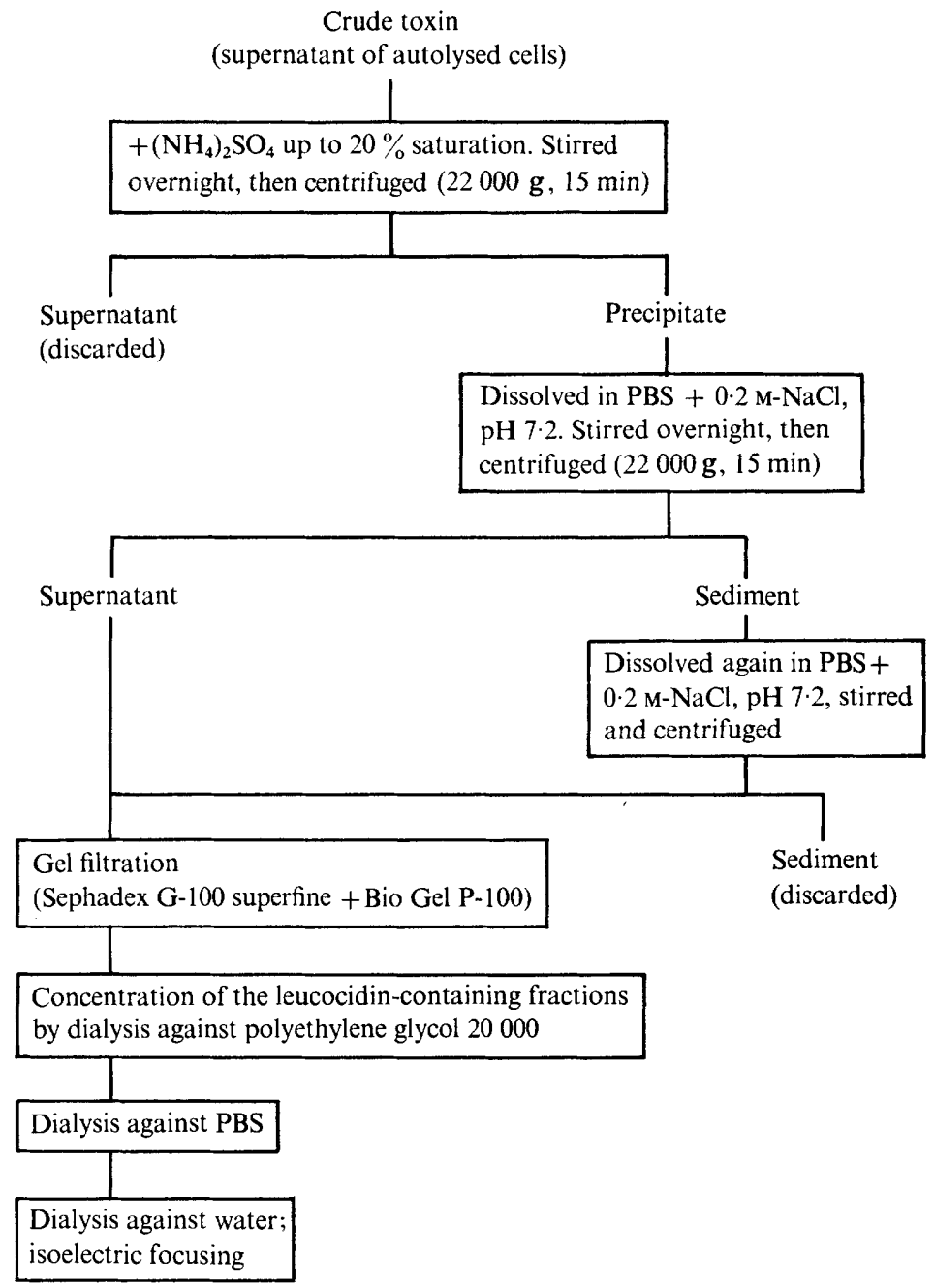

Fig. I. Purification procedure for leucocidin from $P$. aeruginosa

supernatant of the autolysate was precipitated. The protease interferred with further purification steps, since it has a similar molecular weight and isoelectric point (Scharmann \& Balke, 1974).

Step 2: gel filtration. The supernatant fluid from step I ( $10 \mathrm{ml}$ ) was applied to a column $(2.5 \times 100 \mathrm{~cm})$ of Sephadex G-100 superfine previously equilibrated with PBS containing $0.2 \mathrm{M}-\mathrm{NaCl}, \mathrm{pH} 7 \cdot 2$, and eluted with the same buffer. Shortly before the leucocidic activity was expected to appear in the eluate, the effluent was transferred to a second column $(2.5 \times 100 \mathrm{~cm})$ of Bio Gel P-roo equilibrated with PBS containing $0.2 \mathrm{M}-\mathrm{NaCl}, \mathrm{pH} 7 \cdot 2$. This transfer was made by connecting the draining tube of the Sephadex column to the adapter of the Bio Gel column. This 'tandem' gel filtration separated leucocidin and protease (Fig. 2).

All other attempts to separate the two activities, e.g. recycling of the eluate or the use of various types of Sephadex or Bio Gel alone, were unsuccessful. 


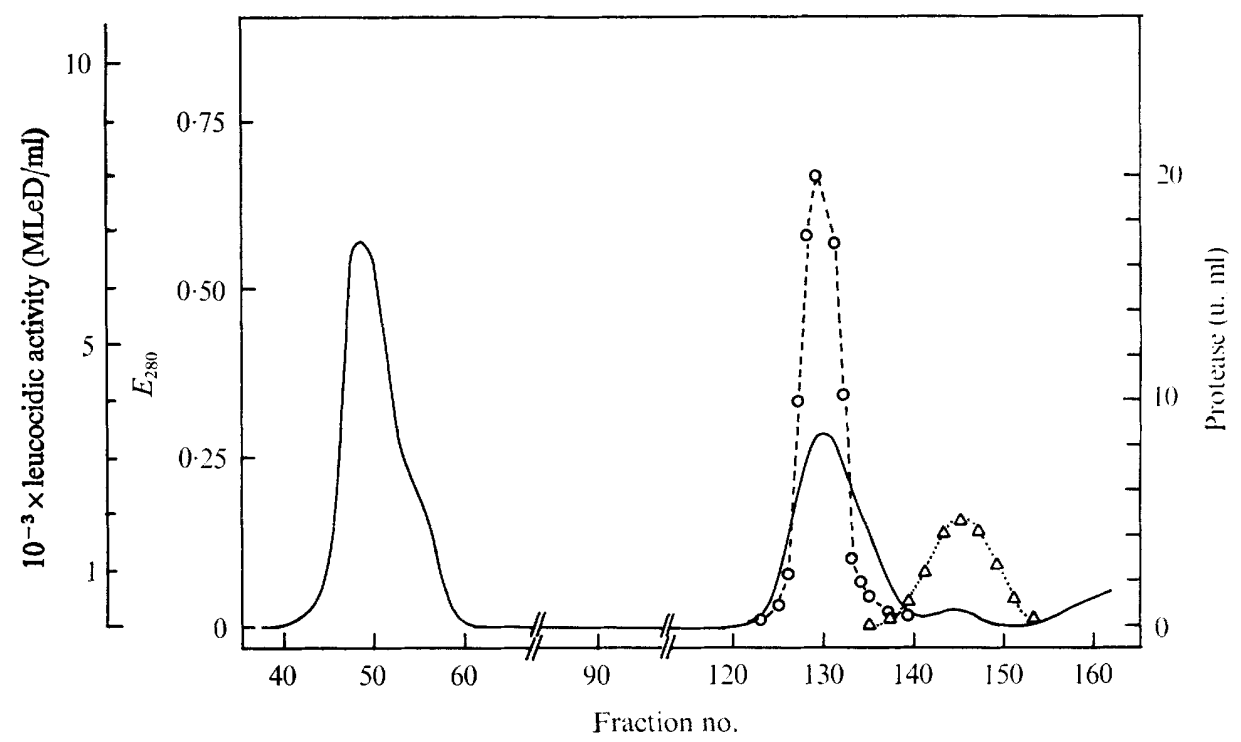

Fig. 2. 'Tandem' gel filtration of leucocidin on Sephadex G-Ioo superfine and Bio Gel P-I00. Ten $\mathrm{ml}$ of solution containing a total of $3 \times 10^{5} \mathrm{MLeD}$ leucocidin ( $87 \mathrm{mg}$ protein) was applied to the column. Fractions of $5.4 \mathrm{ml} \mathrm{h}^{-1}$ were collected. - - , Protein $\left(E_{280}\right) ; \bigcirc---\bigcirc$, leucocidic activity; $\triangle \ldots \triangle$, proteolytic activity.

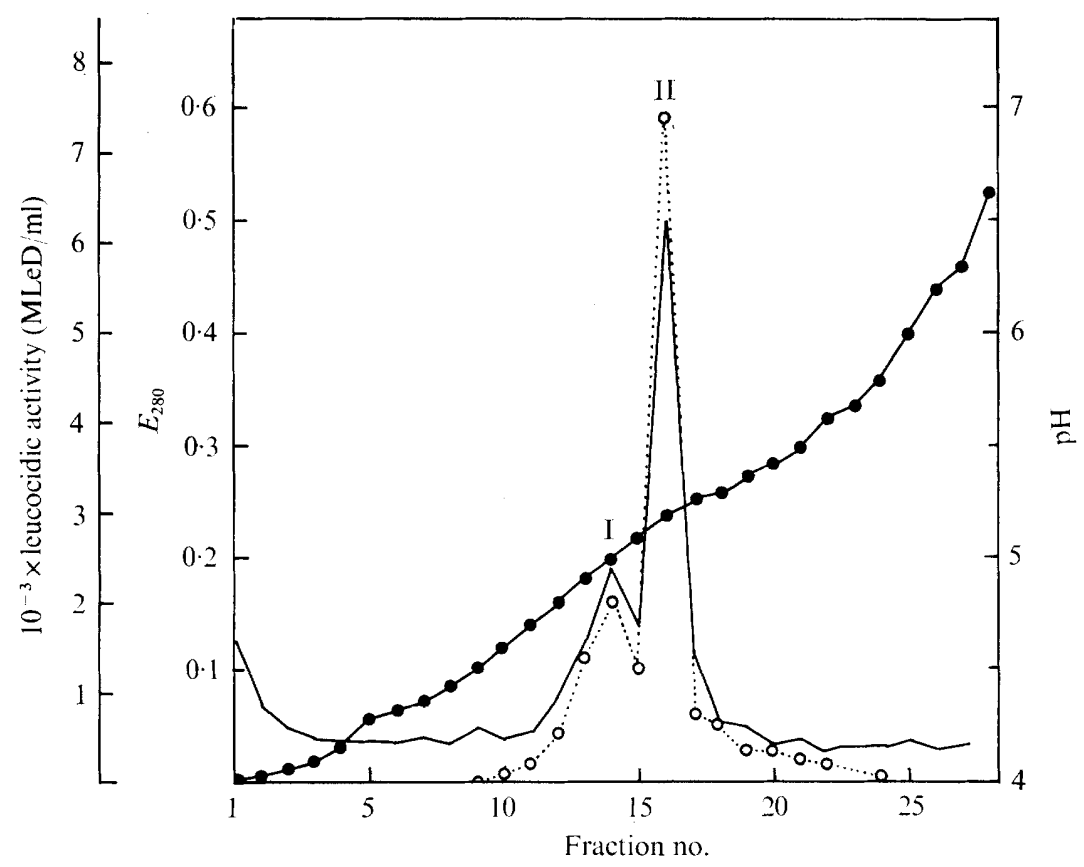

Fig. 3. Isoelectric focusing of $2.5 \times 10^{5} \mathrm{MLeD}$ leucocidin ( $5 \mathrm{mg}$ protein), previously purified by combined gel filtration on Sephadex G-100 superfine and Bio Gel P-IOO. Focusing was performed in ampholine buffer in the range of $\mathrm{pH} 4$ to 6 . Fractions $(4 \mathrm{ml})$ were examined for $\mathrm{pH}$ ( dialysed against PBS at $4{ }^{\circ} \mathrm{C}$ and assayed for $E_{280} \stackrel{(}{\longrightarrow}$ and leucocidic activity $(O \ldots \ldots)$. 
Table I. Purification of leucocidin

\begin{tabular}{|c|c|c|c|c|c|}
\hline Stage & $\begin{array}{l}\text { Volume } \\
(\mathrm{ml})\end{array}$ & $\begin{array}{c}\text { IO }^{-4} \times \text { Total } \\
\text { leucocidin } \\
\text { activity } \\
(\mathrm{MLeD})\end{array}$ & $\begin{array}{l}\text { Total } \\
\text { protein } \\
\text { (mg) }\end{array}$ & $\begin{array}{c}\text { Specific } \\
\text { activity } \\
\text { (MLeD/mg } \\
\text { protein) }\end{array}$ & $\begin{array}{c}\text { Recovery } \\
(\%)\end{array}$ \\
\hline $\begin{array}{l}\text { Supernatant of autolysed cells } \\
\text { Dissolved ammonium sulphate } \\
\text { precipitate }\end{array}$ & 150 & 240 & 1170 & $205 \mathrm{I}$ & $100 \cdot 0$ \\
\hline Ist solution & 10 & 32 & 34 & 9412 & $13 \cdot 3$ \\
\hline 2nd solution & IO & 25 & $3 \mathbf{I}$ & 8064 & 10.4 \\
\hline $\begin{array}{l}\text { Pooled Sephadex G-10o/ } \\
\text { Bio Gel A-I00 eluate }\end{array}$ & 122 & $42 \cdot 7$ & $12 \cdot 2$ & 35000 & $17 \cdot 8$ \\
\hline $\begin{array}{l}\text { Concentrated and dialysed } \\
\text { Sephadex/Bio Gel pool }\end{array}$ & 12 & 42 & 10.9 & $3846 \mathrm{I}$ & 17.5 \\
\hline $\begin{array}{l}\text { Isoelectric focusing } \\
\text { Peak I }\end{array}$ & 6 & I.05 & $\begin{array}{l}4.4 \\
5.7\end{array}$ & $\begin{array}{l}2365 \\
4233\end{array}$ & $\begin{array}{l}0.4 \\
I \cdot 0\end{array}$ \\
\hline
\end{tabular}

Step 3: isoelectric focusing. The leucocidin purified by gel filtration was subjected to isoelectric focusing on a sucrose density gradient and $\mathrm{pH}$ gradients of $\mathrm{pH} 3$ to Io and $\mathrm{pH} 4$ to 6 . In both cases, two bands of precipitation were obtained corresponding to two zones of $280 \mathrm{~nm}$ extinction. Both peaks contained leucocidic activity. The isoelectric points were pH 5.0 \pm 0.05 (peak I) and pH 5.2 \pm 0.02 (peak II) (Fig. 3). Identical results were obtained when the toxin was focused in a density gradient of urea. Isoelectric focusing proved not to be a suitable method for the purification of leucocidin, since only $8 \%$ of the applied toxic activity was recovered. The poor recovery-rate was presumably due to precipitation and inactivation of the toxin at its isoelectric point. A summary of the purification data is presented in Table $\mathrm{I}$.

\section{Polyacrylamide disc gel electrophoresis}

The leucocidin obtained by gel filtration was resolved into five protein bands by polyacrylamide disc gel electrophoresis (Fig. $4 a$ ). Disc electrophoresis of the same preparation in the presence of sodium dodecyl sulphate (SDS) yielded only a single band (Fig. $4 b, c)$. Disc electrophoresis (without SDS) of the two peaks obtained by isoelectric focusing revealed 3 to 4 bands for peak I and 2 bands for peak II (Fig. 5a). However, only I band was observed each time that the electrophoresis was carried out in SDS. Subsequently, leucocidin peaks from isoelectric focusing were once again subjected to disc electrophoresis (without SDS) and the position of the protein bands determined in the unstained gels by scanning at $280 \mathrm{~nm}$. Coincidence of leucocidic activity with all bands was demonstrated by eluting the individual protein bands of the gel and assaying leucocidic activity and protein. The eluted samples all had a similar specific activity. In disc electrophoresis without SDS, the individual leucocidin bands showed the same relative electrophoretic mobility as the preparations (peaks I and II) from which they were eluted (Fig. $5 b$ ). However, in the presence of SDS no differences in the electrophoretic mobility were observed (Fig. $5 c$ ).

\section{Physicochemical properties of the purified leucocidin}

The purified leucocidin ( $10000 \mathrm{MLeD} / \mathrm{ml}$ ) was treated with various proteases such as trypsin, alpha chymotrypsin, pancreatic elastase, papain, subtilisin BPN', subtilisin Carlsberg (each $0.5 \mathrm{mg} / \mathrm{ml}$ ) and pronase (35 PUK-u.). The toxin was completely inactivated by pronase within $30 \mathrm{~min}$ at $37^{\circ} \mathrm{C}$, but was not influenced by the other proteases. The u.v. light extinc- 

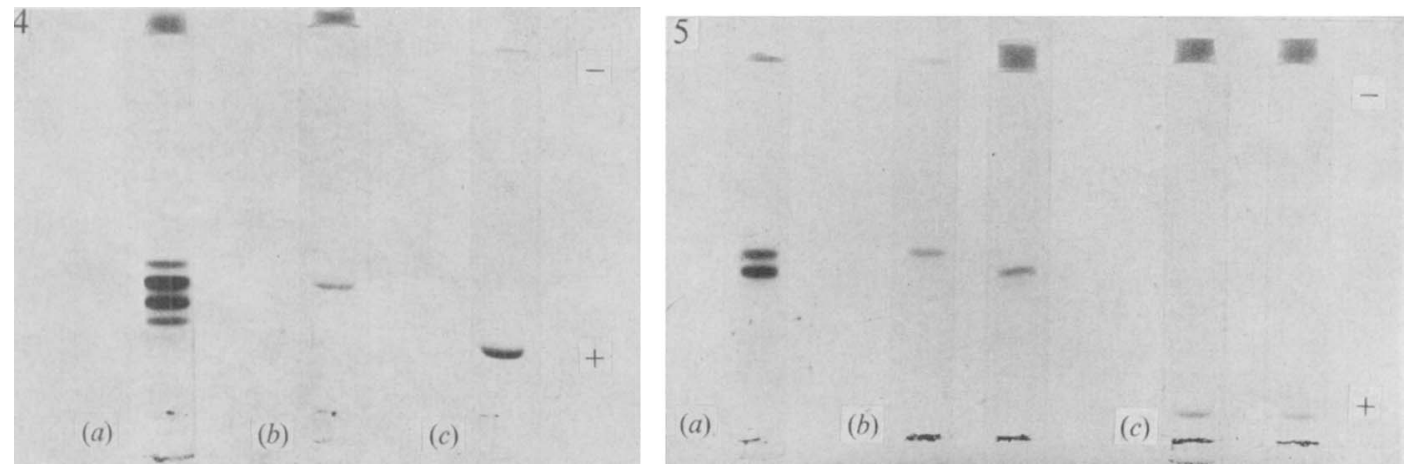

Fig. 4. Polyacrylamide disc gel electrophoresis of leucocidin, previously purified by combined gel filtration on Sephadex G-I00 superfine and Bio Gel P-IOO. (a) I $25 \mu \mathrm{g}$ leucocidin in $7.5 \%$ gel; (b) $55 \mu \mathrm{g}$ leucocidin in $10 \%$ gel with SDS; $(c) 55 \mu \mathrm{g}$ leucocidin in $7.5 \%$ gel with SDS.

Fig. 5. Polyacrylamidedisc gel electrophoresis. (a) Disc electrophoresis of leucocidin peak II, obtained by isoelectric focusing; $(b)$ disc electrophoresis of the single protein bands, cut out and eluted from the unstained gel $a$; $(c)$ disc electrophoresis of the isolated protein bands in gel with SDS.

A $7.5 \%$ gel was used. The position of the tracking dye was marked by indian ink.

tion of the purified leucocidin was typical for proteins. The maximum extinction was at $28 \mathrm{r} \mathrm{nm}$ and the minimum at $250 \mathrm{~nm}$. The molecular weight of the leucocidin, estimated by polyacrylamide gel electrophoresis in the presence of SDS, was 27500 (Fig. 6).

\section{Stability}

A solution of purified leucocidin ( $14000 \mathrm{MLeD} / \mathrm{ml}$ ) lost about $15 \%$ of its activity when kept at $4{ }^{\circ} \mathrm{C}$ for 7 days and about $50 \%$ of its activity when kept at $22{ }^{\circ} \mathrm{C}$ for the same time. At $56^{\circ} \mathrm{C}$ the toxin was inactivated within $60 \mathrm{~min}$ and at $100^{\circ} \mathrm{C}$ within $30 \mathrm{~s}$. At $-30^{\circ} \mathrm{C}$ the leucocidin retained full activity for at least 3 months. No differences of activity were detected when the toxin was diluted in a variety of $0.05 \mathrm{M}$ buffers ranging from $\mathrm{pH} 5.5$ to 9 and kept for 3 days at $4{ }^{\circ} \mathrm{C}$.

\section{Effect of various reagents}

A solution of leucocidin ( $10000 \mathrm{MLeD} / \mathrm{ml}$ ) was adjusted to contain $0.0 \mathrm{I} \mathrm{M}-\mathrm{CaCl}_{2}$ or $0.0 \mathrm{I} \mathrm{M}-\mathrm{MgCl}_{2}$ and kept for $30 \mathrm{~min}$ at $22^{\circ} \mathrm{C}$. Then it was first dialysed against $0.02 \mathrm{M}$-EDTA and subsequently against demineralized water. Leucocidin treated in this way had the same activity as the control when measured with the slide adhesion test.

In the following experiments ${ }^{51} \mathrm{Cr}$ labelled bovine granulocytes were used for the estimation of leucocidic activity: no effect was exerted on leucocidin by cysteine $\left(\mathrm{IO}^{-3} \mathrm{M}\right)$, iodoacetamide ( $\left.\mathrm{IO}^{-2} \mathrm{M}\right)$, and $p$-hydroxymercuribenzoate $\left(\mathrm{IO}^{-4} \mathrm{M}\right)$; various lipids, including cholesterol, sphingomyelin and Folch' brain extracts I, III and V (each roo $\mu \mathrm{g}$, ultrasonically dispersed in PBS) failed to inhibit 100 Folch of leucocidin.

\section{Immunological studies}

Purified leucocidin stimulated in rabbits the production of antibodies, which could be demonstrated in a passive haemagglutination test or by neutralization of the leucocidic activity. In the passive haemagglutination test, antibody titres of $I: 5 \mathrm{I} 20$ were measured. Normal serum did not induce the agglutination of sensitized erythrocytes. The neutralization test proved to be far less sensitive than the passive haemagglutination test. For a $100 \%$ 


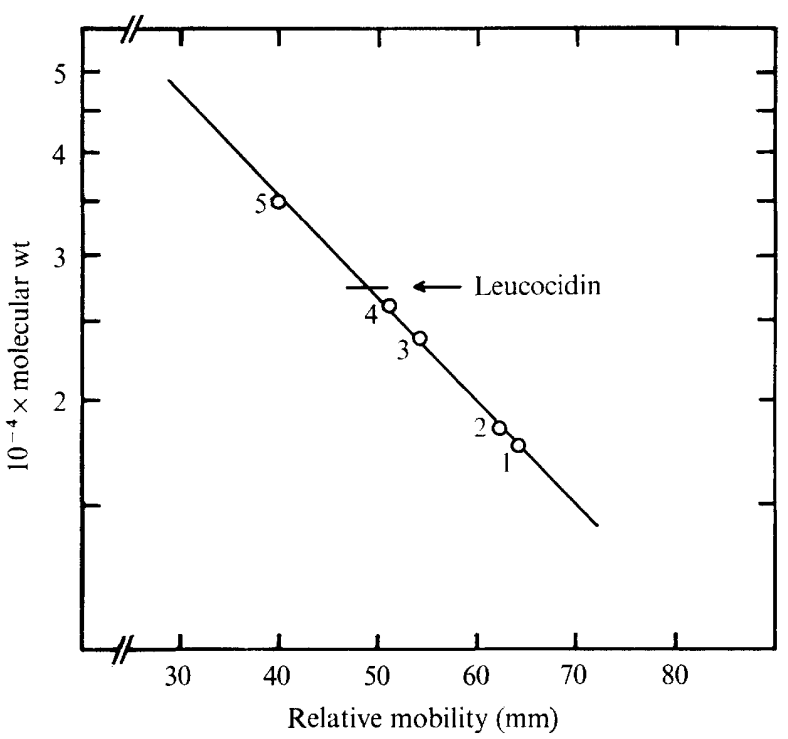

Fig. 6. Determination of the molecular weight of leucocidin by polyacrylamide gel electrophoresis in the presence of SDS. The marker proteins, with their molecular weights, were: I, Myoglobin (17800); 2, lactoglobulin (18200); 3, trypsin (23300); 4, $\alpha$-chymotrypsinogen (25700); 5, pepsin $(35000)$.

neutralization of 100 MLeD of leucocidin a serum dilution not higher than 1:64 was necessary the toxin was also inhibited by undiluted normal serum.

Leucocidin antibodies inhibited the action of leucocidin bound to leucocytes, as shown by the following experiment: bovine granulocytes were mixed with toxin at $4^{\circ} \mathrm{C}$, kept for $\mathrm{I} h$ at the same temperature and washed twice in ice-cold PBS. No cytotoxic affect occurred as long as the cells were cooled. However, raising the temperature to $37^{\circ} \mathrm{C}$ resulted in an immediate destruction of the cells. On the other hand, no destruction occurred when the washed cells were treated with leucocidin antibodies before increasing the temperature.

\section{Cytotoxic effect on various cell species}

Leucocidin damaged granulocytes from humans and from all tested animal species (cattle, sheep, dog, rabbit, guinea pig and mouse). The degree of sensitivity varied among the granulocytes of the different animal species. About I MLeD leucocidin was needed to destroy about 8000 human granulocytes. However, the same number of granulocytes from rabbits was damaged by 0.05 , from mice and guinea pigs by 0.25 , from cattle by 2 to 4 , from sheep by 4 , and from dogs by 8 MLeD. Lymphocytes from humans were twice as sensitive as granulocytes (Fig. 7). The toxin did not induce the release of cathepsin, $\beta$-glucuronidase or alkaline phosphatase from granules isolated from bovine granulocytes. On the other hand, these enzymes were released by the action of haemolysin from $P$. aeruginosa strain $\mathrm{I} 58$.

No morphologic alterations could be detected in erythrocytes of humans, cattle, sheep, dogs, rabbits, guinea pigs, mice and chickens, even after the addition of high concentrations of toxin (5000 MLeD/ml). The same seemed to be true for thrombocytes of humans. Upon the addition of leucocidin no morphological changes of the platelets were observed and no lactate dehydrogenase activity was detected in the suspension medium of the platelets.

Tissue cultures of rabbit kidney cells (Fig. 8), L-cells (Fig. 9), calf testicular cells, HeLa- 

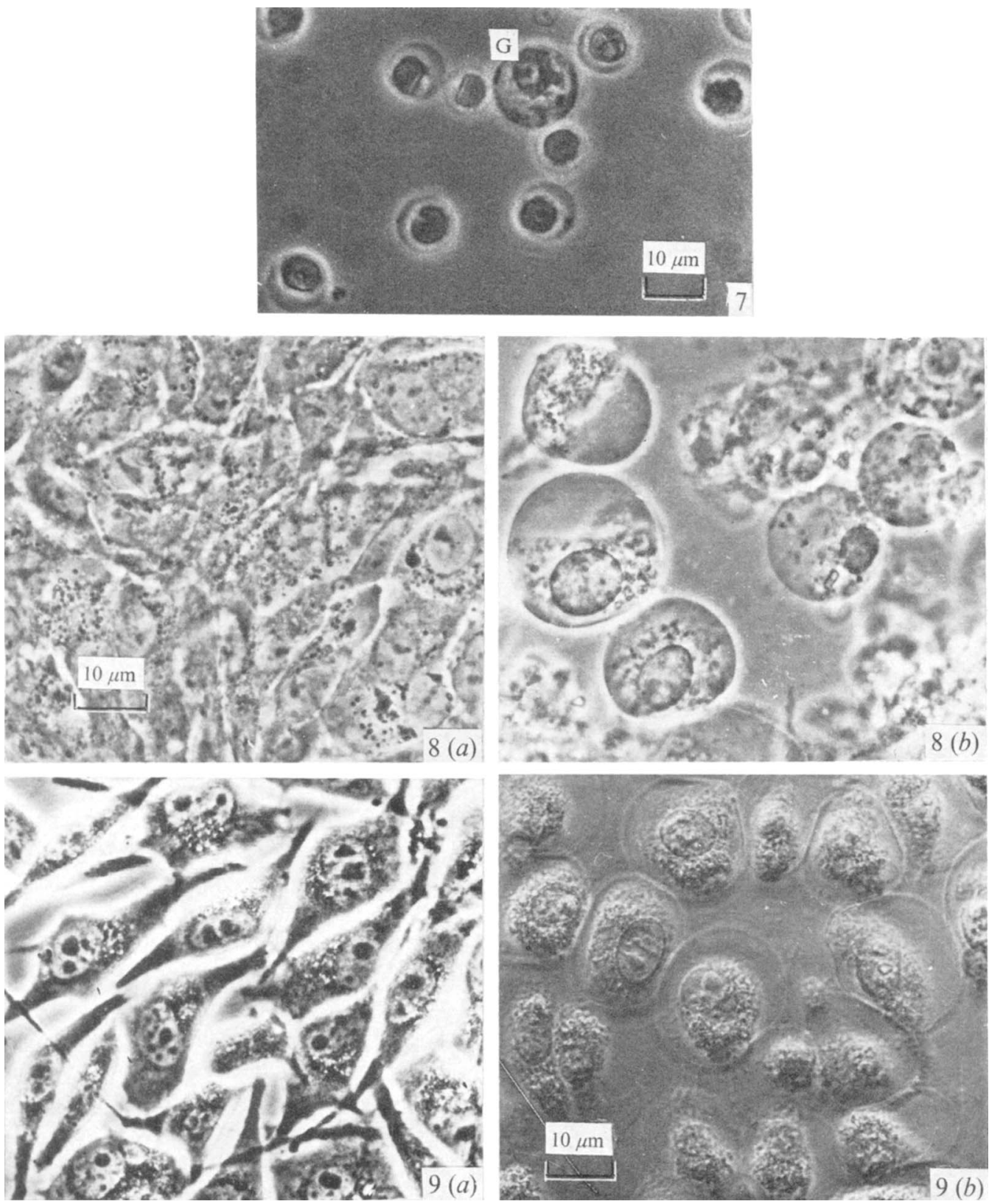

Fig. 7. Cytotoxic effect of leucocidin on lymphocytes from man. G, polymorphonuclear granulocyte. Fig. 8. Rabbit kidney cells, (a) before inoculation, and $(b) 30 \mathrm{~min}$ after inoculation with leucocidin. Fig. 9. L-cells, $(a)$ before inoculation, and $(b) 30 \mathrm{~min}$ after inoculation with leucocidin. 
cells and epithelioid green monkey kidney cells showed a cytopathogenic effect similar to that observed in leucocytes when treated with leucocidin: the cells enlarged and became spherical, but the membrane persisted.

\section{Lethality to mice}

Purified leucocidin was shown to be lethal to mice, death occurring within to to $20 \mathrm{~min}$ from 4 to $8 \mu \mathrm{g}$ quantities. The minimal lethal dose was about I $\mu \mathrm{g}$.

\section{DISCUSSION}

Purified leucocidin exhibited the same properties as most of the other cytolytic toxins of bacteria (Bernheimer, 1970). It was inactivated by pronase, thermolabile, not dialysable, and gave rise to neutralising antibodies. Some of these characteristics, as well as the u.v. absorption spectrum of the toxin indicate its protein nature. The inability of $p$-hydroxymercuribenzoate and iodoacetamide to inhibit the leucocidic activity suggest that the active moiety of the toxin molecule does not contain free sulphydryl groups.

The purification of leucocidin was complicated by the presence of a protease (elastase) with a similar isoelectric point (pH 5.7 and $\mathrm{pH} 6.45)$ and molecular weight (22 300) (Scharmann \& Balke, 1974). They were separated by a combined 'tandem' gel filtration on Sephadex G-I00 superfine and Bio Gel P I00. This gave a toxin preparation which was homogeneous in molecular weight as shown by sodium dodecyl sulphate gel electrophoresis. However, this preparation was heterogeneous in charge, since it was separated by isoelectric focusing into two components exhibiting leucocidal activity. Moreover, these components could be further separated into several bands with toxic activity by means of disc electrophoresis without SDS. The isolated bands retained their homogeneity and electrophoretic mobility. The differences in the charge of the purified leucocidin preparation may have resulted from the transformation of cell-bound precursor toxin into the free toxin (Scharmann, 1976) or may be caused during the bacterial autolysis. The supernatant of autolysed cells exhibited the typical 5-band pattern of the gel-filtrated leucocidin. Six \& Harshman (1973) described two forms of staphylococcal $\alpha$-toxin, also showing different electrophoretic mobility in disc gel electrophoresis but identical mobility in SDS gel. Heterogeneity in charge of crystalline insulin due to a deamidation reaction has been reported by Carpenter \& Hayes (1963). The insulin derivatives had been prepared either by mild acid treatment or by the action of trypsin or carboxypeptidase $\mathrm{A}$ on insulin.

Leucocidin damaged the leucocytes of all tested animal species and elicited a similar cytopathogenic effect on the cells of various tissue cultures. The toxin did not damage erythrocytes or thrombocytes. The relatively broad spectrum of cells sensitive to leucocidin suggests that the component which is essential for the reaction with leucocidin may be a frequent constituent of mammalian cells. Isolated leucocyte granules were not destroyed by leucocidin but by haemolysin of the same $P$. aeruginosa strain. These findings correspond to those of Bernheimer \& Schwartz (1964), who reported that lysosomes are damaged only by those substances that also induce lysis of erythrocytes.

This work was supported in part by the Deutsche Forschungsgemeinschaft. 


\section{REFERENCES}

ANson, M. L. (1936). The estimation of cathepsin with hemoglobin and the partial purification of cathepsin. Journal of General Physiology 20, 565-574.

Behrens, M. \& EsCh, F. (I963). Gewinnung von Leukozyten aus Rinderblut unter Verwendung von Wasser als Hämolytikum. Experientia 19, 406-407.

BERK, R. S. (1964). Partial purification of the extracellular hemolysin of Pseudomonas aeruginosa. Journal of Bacteriology 88, 559-565.

Bernheimer, A. W. (1970). Cytolytic toxins of bacteria. In Microbial Toxins, vol. I, pp. 183-212. Edited by S. J. Ajl, S. Kadis and T. C. Montie. New York and London: A.cademic Press.

BERNHEIMER, A. W. \& SCHWARTZ, L. L. (1964). Lysosomal disruption by bacterial toxins. Journal of Bacterio$\log y$ 87, I IOO-I IO4.

Bessey, O. A., Lowry, O. H. \& Brock, M. J. (1946). A method for the rapid determination of alkaline phosphatase with five cubic millimeters of serum. Journal of Biological Chemistry 164, 32 I-329.

CARPENTER, F. H. \& HAYEs, S. L. (1963). Electrophoresis on cellulose acetate of insulin and insulin-derivatives: correlation with behaviour on countercurrent distribution and partition-column chromatography. Biochemistry 2, 1272-I 277 .

Cox, C. B., Hardegree, C. \& Fornwald, R .(1974). Effect of tetanolysin on platelets and lysosomes. Infection and Immunity 9, 696-70r.

DAvis, B. J. (1964). Disc electrophoresis. II. Method and application to human serum proteins. Annals of the New York Academy of Sciences 121, 404-427.

DulBECCO, R. \& VoGT, M. (1954). One-step growth curve of western equine encephalomyelitis virus chicken embryo cells grown in vitro and analysis of virus yields from single cells. Journal of Experimental Medicine 99, $183-199$.

Fishman, W. H., Springer, B. \& Brunetti, R. (1948). Application of an improved glucuronidase assay method to the study of human blood $\beta$-glucuronidase. Journal of Biological Chemistry 173, 449-456.

Gladstone, G. P. \& van Heyningen, W. E. (1957). Staphylococcal leucocidins. British Journal of Experimental Pathology 38, 123-I 37.

HEGNER, D. (1968). Isolierung und Enzymbestand von Granula aus polymorphkernigen Leukozyten des peripheren Rinderblutes. Hoppe-Seyler's Zeitschrift für physiologische Chemie 349, 544-554.

ScharmanN, W. (1976). Formation and isolation of leucocidin from Pseudomonas aeruginosa. Journal of General Microbiology 93, 283-291.

ScharmanN, W. \& Balke, E. (1974). Untersuchungen über eine Protease (Elastase) von Pseudomonas aeruginosa. I. Bildung und Reinigung der Protease. Hoppe-Seyler's Zeitschrift für physiologische Chemie 355, 443-450.

SCHARMANN, W., JACOB, F. \& PorstendöRfER, J. (1976). The cytotoxic action of leucocidin from Pseudomonas aeruginosa on human polymorphonuclear leucocytes. Journal of General Microbiology 93, 303-308.

Seiler, F. R., Sedlacek, H. H., Kanzy, E. J. \& LaNG, W. (1972). Uber die Brauchbarkeit immunologischer Nachweismethoden zur Differenzierung funktionell verschiedener Lymphozyten. Behring Institute Mitteilungen 52, 26-72.

Sezen, I. Y., Scharmann, W. \& Blobel, H. (I975). Wirkungen eines gegen gereinigte Protease von Pseudomonas aeruginosa hergestellten Antiserums. Zentralbatt fur Bakteriologie, Parasitenkunde, Infektionskrankheiten und Hygiene (Abteilung I) A231, I26-I32.

Six, H. R. \& Harshman, S. (1973). Purification and properties of two forms of staphylococcal toxin. Biochemistry New York 12, 2672-2677.

Weber, K. \& OsBorn, M. (1969). The reliability of molecular weight determinations by dodecyl sulfatepolyacrylamide gel electrophoresis. Journal of Biological Chemistry 244, 4406-4412. 